\title{
UNLOCKING PLANNING THROUGH EVERYDAY LIFE NARRATIVES: THE CASE OF ISTANBUL, ESENLER HAVAALANI NEIGHBOURHOOD
}

\author{
Ozge TEKCE, PhD Student, Istanbul Technical University, Faculty of Architecture, \\ Department of Urban and Regional Planning, Turkey. \\ Zeynep GUNAY, Assoc. Prof.Dr., Istanbul Technical University, Faculty of Architecture, \\ Department of Urban and Regional Planning, Turkey.
}

\begin{abstract}
As the global urban agenda is increasingly being restructured by a major emphasis on the reproduction of urban space as an opportunity space both in the developed but more in the developing world, the implications on the society become a major subject in the current urban discourse. The current urban agenda of Istanbul implies constant pressure to renewal every square meter of the urban spatiality including inner-city slums, peripheral migrant neighborhoods, and historic neighborhoods. The casualties in the process of transformation of cities do not solely reflect the change of ownership patterns, the disappearance of security, the destruction of urban fabric; the same process also draws on the loss of communities, their heritage, and memories. The mechanized system created by the standardization on transformation approach erases the 'simple' everyday life routines, and new urban areas are created where the individual cannot exist. Based on a story of one family in Istanbul's Esenler Havaalani Neighbourhood, the research that is constructed upon in-depth interviews attempts to explore everyday life allows and to showcase a holistic quest on the need for inclusiveness, empowerment, and resilience in a world of isolation, fragmentation, and displacement. Listening to the stories of people and learning from their everyday life narratives is therefore essential for strengthening the bond between the city and society in unlocking planning.
\end{abstract}

\section{Keywords}

Urban Renewal, Everydaylife Narratives, Inclusiveness, Segregation

\section{Introduction}

With the capitalist development process, space faced a serious transformation for the first time by moving away from its usual, stagnant, and taken-for-granted state. In this period, which Brenner and Theodore (2002) define as the new urban fiction in which neo-liberalization is urbanized, space has become a power center where the capital, politics, and local relations intersect. This situation brings the place to a position that is evaluated only on the value of the land. Depending on neoliberalism's evergrowing geography, cities are characterized as the mechanism of enrichment and the center of capital (Harvey, 2012; Molotch, 1976; Smith, 2002). Today, the reproduction of space, changing land values through neo-liberal policies, reveals the value differences between regions (Tekeli, 2011); where the value differences are radicalized, the pressure for transformation increases. Thereby, as a result of the 
change in the economic and socio-political conjuncture in the transformation of cities, the ownership structure of the urban space is redefined.

The transformation in the space directly interferes with the daily life of the individual. From the social scientist's point of view, the breaking point in the discussion of everyday life is seen as urbanization, which is defined as the transition from traditional society to modern society (Simmel, 1996; Tönnies, 1988). Indeed, the importance of research about daily life is explained by the fact that knowing the daily routines of individuals sheds light on the social life and, accordingly, the spatial setup (Lefebvre, 1968). The city which shapes the daily life of the individual also stands out as a space where individual existence struggles. In addition, discussions of everyday life, which is the narrative of the individual's unique relationship with space, become more of an issue again (Crawford, 2005; De Certeau, 2011; Lefebvre, 1968).

Everyday life consists of habits and ordinary ones. Every conscious or unconscious movement, every situation is included in the definition of daily life and has different meanings for the individual even if it is not noticed. Scrutinizing everyday life on a theoretical basis, Lefebvre (1971) emphasizes that everyday life has static and taken-for-granted features in his definition of daily life, but also mentions its unceasing power. Moreover, the view that everyday life consists of intertwined relationships and daily practices is common (Bourdieu, 1995; De Certeau, 2011). Accordingly, any intervention to the city is also considered to be an intervention to the society and its daily practices and habits (Gregory and Walford, 1989). The reproduction of everyday life evolves in itself dependi

$\mathrm{g}$ on the production of the society and individual dialectic in which the original is ignored. The daily life practices that emerge from the unique values of each individual leave their place to new standardized lifestyles for everyone. Utilizing from this perspective, the city represents a life form that is reproduced with the abandonment of the places where the sense of belonging is felt.

Everyday life narratives allow the society and space to be examined as holistic and interdependent variables, against the neo-liberal urbanization policy that separates space from society and society from space. For this reason, it is important to focus on everyday life, as light the way for the life of citizens in the capitalist world order, where society is segregated and stratified day by day. The fact that spatial decisions and policies have a direct impact on the daily lives of individuals also proves this situation. In recent years, the global agenda has drawn attention to the importance of social integration as the key to creating a society for all. What is more, it stands out that every individual in the society should take an active role in the city due to the common rights and responsibilities they have. However, the way the built environment is planned or transformed today is insufficient to include and empower citizens. Failure to achieve social integration and the planning of the city by only a part of the social cause to social segregation (Atkinson and Bridge, 2005; Smith and Williams, 2013). Notions such as segregation, exclusion, and individualization that emerged as a result of the disintegration in the social structure stand out as the social reflections of the decisions taken (Lees, 2008; Zukin, 1987). The reason for this problem is that society is not given a voice in policymaking and urban interventions. In the process of planning or transforming the physical environment, considering society and space as integral and interdependent variables plays a decisive role in the participation of an inclusive and democratic society in everyday life.

The scope of this research focuses on Esenler Havaalanı Neighbourhood, which is the first place declared as a transformation area within the extent of Turkey's Law No. 6306 on Transformation of Areas Under Disaster Risk. It is therefore the particular goal of this research to call for a critical perspective based on empirical insight into the everyday life narratives of communities within transforming cities. The main question of this research is "What is the role of daily life narratives in changing the planning approach and providing a perspective of inclusiveness?". Therefore, for this research, it is critical to understand the situations described as social problems from the perspective of society, to be perceived on the basis of 
daily life, and to help create areas of struggle. Since social behaviors reflect the meaning of the space, it is essential to draw attention to these daily life narratives in order to comprehend the space. Due to the research being based on relationality with the subject, a qualitative research method is used. As a consequence, the research focuses on 'narrative' or 'life histories', which reveal the social behavior of people within the framework of traditional social behavior foundations. The research launched with the pledge of experiencing and questioning the urban transformation process by listening and feeling the daily life story of the family living in the Istanbul Esenler Havaalanı Neighborhood. Family members are Şenay and Atilla. During the research process, observations were made before and after the urban transformation in the neighborhood. In addition, after the urban transformation project was implemented, the ethnographic research was completed by spending 4 months with with Şenay and Atilla in the place where they lived.

In line with the stated purpose, the research was designed as three titles: (I) Discussions of space and society within the framework of the neoliberal agenda, (ii) The effects of urban transformation and urbanization on daily life practices, (iii) Transforming everyday life of a family living in Esenler Havaalanı Neighbourhood. These three titles, evaluated within the scope of the research, are important because they shed light on the social and social problems that arise when planning is not inclusive.

\section{Discussions of Space and Society within the Framework of the Neoliberal Agenda}

Cities come to the fore with their land values in the global market shows that cities are presented to the global economy not with their original values, but with their land values. Hence, everything that is nonsuitable for global capital ejaculates from the system. Herewith, cities emerge as organized power centers where the capital, state policies, and localized social relations intersect (Brenner, 1999). Brenner and Theodore (2002) hold the view that neo-liberalization leads to political decisions in cities, and the urban planning process cannot be considered independently. As urban spaces become commodities, cities do not come to the fore with their life values, but have an abstract space feature that stands out with their transformation value; eventually, they become an instrument for potency which wants to establish complete control over the place (Crawford, 2014; Lefebvre, 1971). In this way, the leaning for urban renewal movements is increasing as a response to the degeneration in urban spaces through urban policies and planning approaches.

Cities transformed by neoliberal policies appear as newly produced spaces whose frames, meanings and functions have completely changed (Brenner and Theodore, 2002). This situation causes cities to become more similar to each other and to lose their original values (Lovering \& Türkmen, 2011). Therefore, urban policies, urban plans, or every intervention to the city affects the individual as the major actor living in the city, not only physically but also socially. The fact that current planning approaches are designed by plans as supports the domestication of the society and cities (Atkinson, 2001; Smith, 1996). Cities that become the same and move away from their original value create the consumer society structure. Foucault et al. (2008) liken this way of managing cities to entrepreneurial companies.

Lefebvre (2014) interprets the new social structure produced by urbanization, the individuals "domesticated with cappuccino" as Zukin (1995) puts it, as the consuming society of consuming cities. Moving away from the expired in the consumer society construction causes the foundations of social and social disintegration. The view that major development projects put pressure on the social and physical structures of cities, such as social polarization or gentrification, is increasingly taking place in the urban agenda (Brenner and Theodore, 2002), which is an obstacle to achieving social integration. 


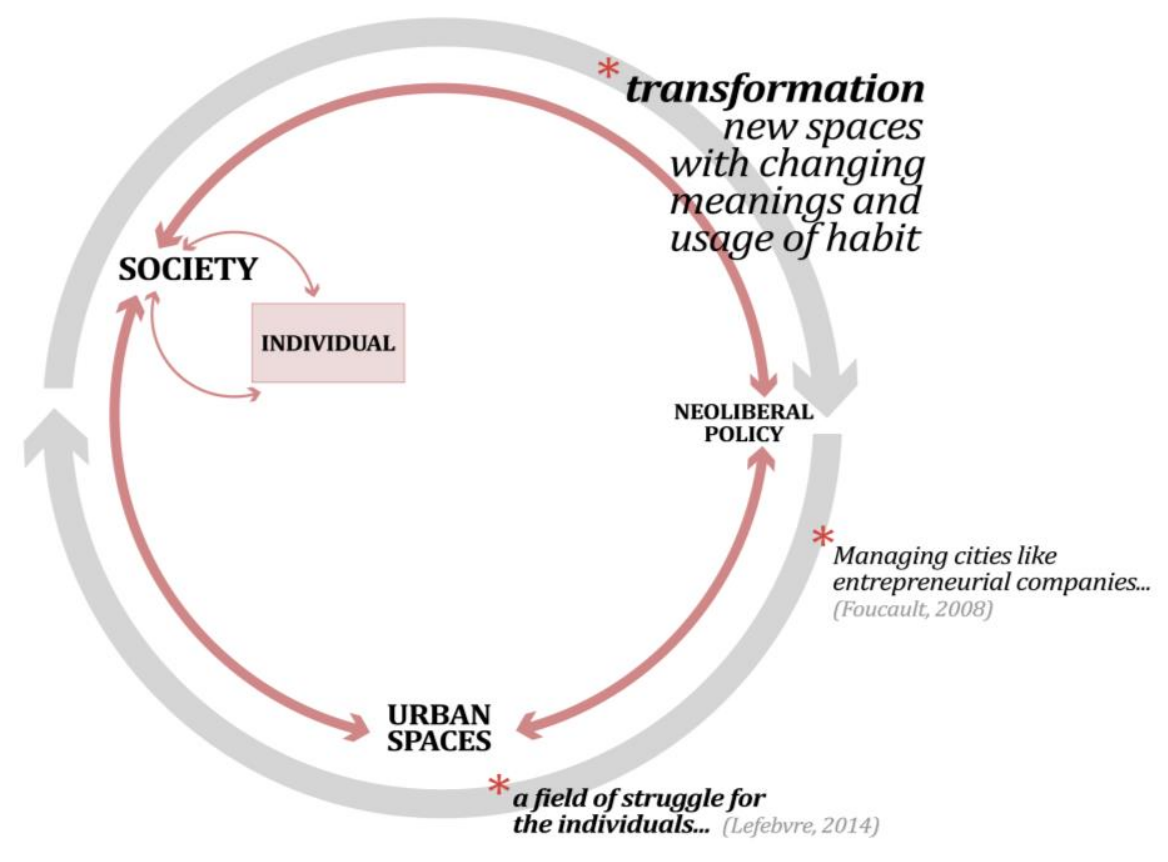

Figure 1 Transformation pressure, re-created of space and society.

As a result, cities presented to the global economy as a planning purpose and as a result, the new consuming society target (Castells, 1994; Lefebvre, 2014; Smith, 1996) bring along the discriminating power that takes place in cities. The emergence of dual urban structuring created by increasing inequality and segregation environments by reflecting on the urban place (Kiper, 2004), and depending on the continuous reproduction of the place, cities become a field of struggle for the individuals living in the city (Lefebvre, 2014). It is important to draw attention to this issue in terms of emphasizing that planning should be community-oriented and together with the citizens. Since the urban planning approach is not life-oriented, the bond between society and the city will inevitably be damaged (Crawford, 2005). Considering that the most fundamental problem in today's cities is shaped by urban policies that are not inclusive, it is underlined that the unlocking of planning will only be possible with inclusion and empowerment.

\section{The Effects of Urban Transformation and Urbanization on Everyday Life Practices}

The value of research on everyday life is explained by the fact that knowing the daily routines of individuals sheds light on the social life and accordingly the spatial setup (Lefebvre, 1971). While the city, which shapes the daily life of the individual, comes to the fore as a place where individual existence struggles, the discussions of everyday life, which is the narrative of the individual's original relationship with the space, have importance again (Crawford, 2005; De Certeau, 2011; Lefebvre, 1971; Tekeli, 2000). The first signals of change in the habits of individuals are given as the heterogeneous and chaotic texture of urban life replaces the cycle that progresses in the fixed order of rural life. Moreover, spatial interventions are at the forefront of the causes of the uncontrolled development of everyday life experiences. The reproduction process of capital in space does not only cause a transformation in physical life but also affects individual life and reproduces the daily lives of individuals. Though Lefebvre (2014) describes space as the product of society, emphasizes that new urban spaces are created where the individual cannot exist as a result of the produced modern times, digest in the daily lives of ordinary 
people in a mechanized system. Furthermore, as a result of the unequal frame mounting from the distribution of capital on the global agenda, new debates arise about the representations of daily life.

In view of urbanization, which is defined as the tending from traditional society to modern society, the rapid retiring of the city and urban space from its social content brings along problems such as isolation, separation, and displacement (Atkinson and Bridge, 2005; Lees, 2008; Smith and Williams, 2013; Zukin, 1987; . The imposition of a new manner of life by the powerful segment of society through planning or urban policies reveals the social reflections of spatial injustice and provides an environment for direct intervention in everyday life (Lefebvre, 2006). Original values are ignored and replaced by standardized new lifestyles for everyone in cities. Connerton (2011) defines as "making modernity forget", is considered together with the concern of creating a new society, forgetfulness becomes a part of the new urbanization policy and practice. The ability of today's societies to preserve their unique and traditional values from the past is gradually lessening and tends to disappear in the past (Giddens, 1999; Jamerson, 2008). The citizens, who are faced with changing their habits, feel as if they are separated and not included in the place they live. Thus, the city becomes to represents a life form that is reproduced with the abandonment from the places where the sense of belonging is felt.

Everyday life of individuals in the process of urban and space transformed within the framework of the neoliberal socio-political conjuncture, (i) from the traditional society structure to the individualized 'modern homogeneous' structure (Bourdieu, 1995; Fischer, 1975; Tönnies, 1988; Wirth, 1964); (ii) from a social structure with collective memory, a shared culture, and a sense of belonging to a segregated and alienated society structure (Bourdieu, 1995; Debord, 1984); (iii) from the systems of life that lack social solidarity relations to exclusion and lack of social capital (Durkheim, 1976; Jacobs, 1961; Park and Burgess, 1925; Simmel, 1996). Within the framework of reproduction in the individual-society dialectic, 'non-community cities' emerge, where social integration cannot be achieved and social cohesion is damaged day by day, due to the distancing of social memory from the unique. Understanding all these situations from the perspective of society is only possible by focusing on the everyday life narratives of the individual.

\section{Transforming Everyday Life Narratives in Esenler Havaalanı Neighborhood}

In this section of research, research findings on Esenler Havaalanı Neighborhood, Turkey's first urban transformation project, are presented. This neighborhood was declared as a risky area within the scope of Law No. 6306 on Transformation of Areas under Disaster Risk; which enacted in 2012. Focusing on the change of daily life routines in transforming cities, the experiences in the transformation process and the effect of the family on the reproduction of daily life are discussed regarding what a family says.

\subsection{Spatial Development Process of Esenler Havaalanı Neighborhood}

Esenler Havaalanı Neighborhood, located in the center of Esenler District of Istanbul, is one of the first settlements of the district. It has an important place in terms of its location, as it is close to the districts that can be described as the commercial centers of Istanbul. Therefore, there has been a rapid population growth in Esenler district between 1970 and 1982. The increasing population density of the district coincides with the urbanization process of Turkey, which is divided into four periods: 1923-1950, 1950-1980 (Tekeli, 2012), 1980-2000 and 2000 (Ataöv and Osmay, 2007). 


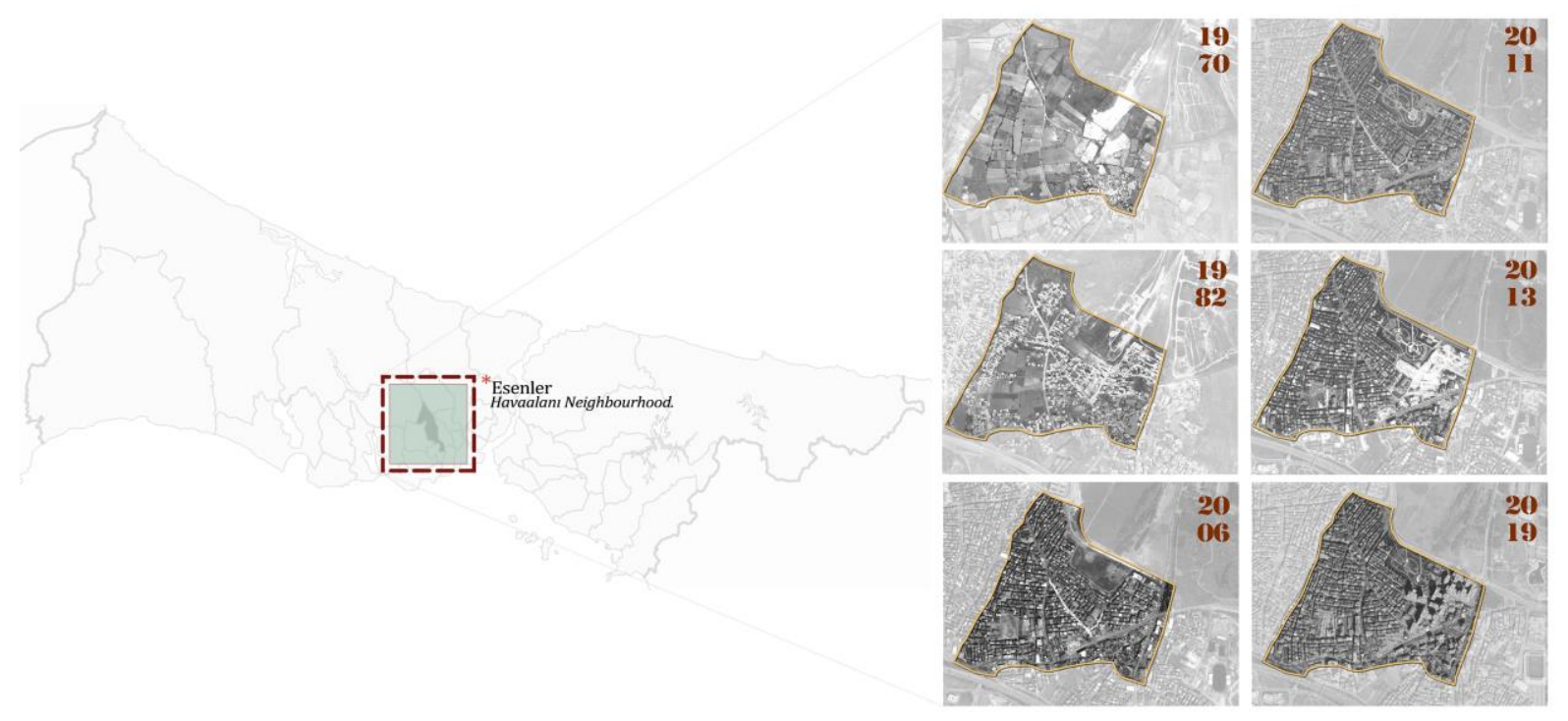

Figure 2 Location and spatial transformation (1970-2019) of Esenler Havaalanı Neighborhood

Between 1923-1950, which is defined as the first period, the number of shanty houses increased day by day in the city periphery. This situation started to come to the fore as the beginning of the problems of construction in the cities. Slum structures emerged in the first period of urbanization in Turkey. It continued as a subject of struggle in the following periods as well. The years between 1960 and 1980, when the Turkish economy grew, are defined as the second period. In this period, migration from the village to the city increased and the housing problem expanded all over Turkey (Tekeli, 2011). In this period, the licensed housing stocks in the city started to transform into multi-storey and high-density apartments. During this period, 'gecekondu' areas were altered to legal areas in the city macroform (Şenyapılı, 1998; Çavuşoğlu, 2014). Esenler Havaalanı Neighborhood is an example of such settlements.

The third period which was defined by cities that were affected by an open liberal economy and globalization is 1980-2000. In this period, major metropolitan projects was scheduled and the effect of neoliberalism on the city was observed. (Yalçıntan and Çavuşoğlu, 2010). The post-2000 period, on the other hand, appears as the period in which the cooperation of the local government with the private sector accelerated and the transformation was evaluated strategically (Ataöv and Osmay, 2007). In this context, the most important development of the post-2000 period in terms of spatial transformation is the inclusion of urban transformation in laws. Urban transformation in Istanbul emerges as a tool to change the face of the city and re-establish the city (Aksoy, 2014).

Before the old houses of the interviewed family were transformed; It has a plot of 154 square meters. It has 90 square meters on the ground floor and 100 square meters on the other 3 floors. Their house is a family apartment built by themselves in 1978 with their own efforts. The family continued to live in this house until 2012.

After being declared a risky area within the scope of Law No. 6306 on the Transformation of Areas Under Disaster Risk in 2012, the residents of the neighborhood, who left their homes, started to look for a new house to rent in that period. Due to the fact that the neighborhood was declared a project area, the rents of housing in Esenler District increased. Therefore, the residents of the neighborhood had great difficulties in finding a house and had to struggle with economic difficulties. In addition, with the evacuation of the neighborhood and the moving of the residents to their new homes, the concerns about the details of the project started to increase. As the houses started to be demolished, the residents of the neighborhood mostly mentioned that they felt aggrieved because they could not get information about the process. During the project, the residents of the neighborhood said that they were invited to the 
meetings, but they could not get answers to their questions at the meetings. Neighborhood residents stated that clear information about the project is not shared and the process does not progress transparently. This situation, the progress of the transformation without including the residents of the neighborhood shows that the destruction of the neighborhood is evaluated only physically and the lives and memories of the individuals living here are ignored.

It was a very difficult process, we do not know where and how we will live, and we do not know when and how our house will be completed. Can you imagine the desperation? As everyone in the neighborhood is looking for a house at the same time, rents have also increased. Nobody wanted to move away from where they live. So, I want it to be seen how we suffered and disappointed. (Şenay, Personal Interview, 12.05.2018).



Figure 3 The transforming frame of the space in Esenler Havaalanı Neighborhood.

\subsection{The Transforming Narratives of Everyday Life}

With the completion of the urban transformation, the Havaalanı Neighborhood has become a closed site with 2373 flats, 12 blocks and 55 workplaces. 1403 flats and 32 workplaces were built for beneficiaries, and 970 flats and 23 workplaces were built to finance the project (Emlakkonut, 2016). It has been difficult for all neighbors like the Çalık family to abandon the usual life and move to an unfamiliar order both physically and socially. The fact that the residents of the neighborhood could not be organized in their new but small houses and that their belongings could not fit in their new homes caused them to change their daily lives. 
How can we host guests in a house where we can't even fit the furniture? If I have guests to, where will I sleep? You can't invite anyone to your house. (Şenay, Personal Interview, 17.09.2019).

When the needs, demands and social structures of the beneficiaries are not taken into consideration while the transformation projects are being carried out, the constructed houses become unusable living spaces. This situation causes the basis of the discussion of whether cost-oriented or individual-oriented production. It is known that many houses constructed in the current urban agenda ignore individual and community life. In each interview, narratives about the 'learning the difficulties of living on the site' were recorded. Individuals feel the pressure of transformation on themselves and have to change their behaviors accordingly. The fact that these designed areas do not match the lifestyles of the families living in Esenler Havaalanı Neighborhood reveals that the projects produced do not come into contact with the public and prevent the public from feeling belonging. It is an undeniable fact that transformation cannot be thought of independently of people, due to its spatial as well as social, economic and political dimensions.

This emerging alienation causes intolerance in the new society structure Atilla explains this situation; 'Our neighborhood was our family'. Each of the interviewees talks about the lack of sense of belonging both in the houses they rent out and the site they live in. All of them emphasize that they feel 'in a closed box' in a high-rise complex while living in a family apartment, a neighborhood unit. Even when talking about the increasing number of facilities the interviewees emphasized that the main problem was to be individualized.

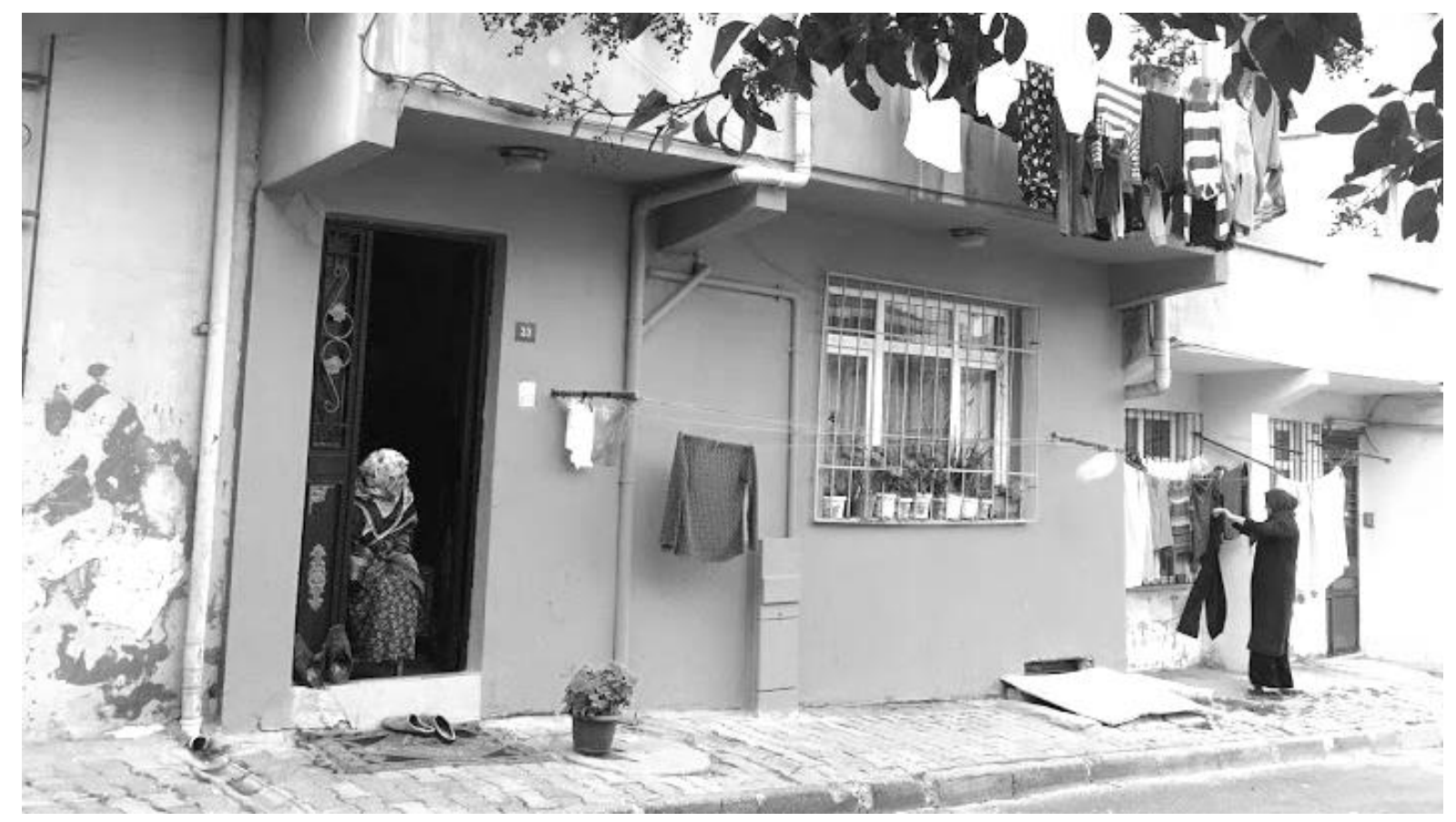

Figure 4 Esenler Havaalanı Neighborhood, old neighborhood life.

\section{Conclusion}

Everyday life and space are two interdependent/related notions. As a result of the effects of globalization being felt more in cities and the inequality expanding from the distribution of capital, the everyday life of society and individuals is changing. It is possible to say that everyday life is structured through space, and space causes the transformation of society by changing everyday life and social framework rather than 
creating a new society. Thereby, every planning decision or urban policy is taken for space directly affects human life. In case, ensuring that cities are livable spaces for everyone is possible by 'togetherness', 'inclusiveness', and 'empowerment'. It is necessary to have a voice in the plans and urban policies prepared for the areas where society lives. Otherwise, all the decisions taken create spaces that the society does not feel belonging to, and this causes social degeneration. In the decisions to be taken on the urban space, in the policy proposals to be presented on the city, or in the new perspective to be included in the planning, everyday life and social-economic conjuncture should not be ignored.

The first step to participation is to ask for ideas and listen. Listening is possible by being a partner in daily life narratives. Focusing on everyday life narratives as part of the ethnographic research process creates an environment for the politics and practice of urbanization to be evaluated within the framework of the individual's life. In this context, in the research based on the narrative of the family interviewed in Esenler Havaalanı Neighborhood, many results have been obtained regarding the effect of the transformation of the space on daily life practice.

In the transformation process in Esenler Havaalanı Neighborhood, the fact that physical transformation is the dominant actor rather than families, ignoring the difficulties experienced in the process, and the neglected to the people living in the neighborhood show that the transformation is viewed unilateral. The construction and organization of spaces that are deemed appropriate for the weak by the powerful section of the society, and thus the creation of 'appropriate' lifestyles, creates an environment for direct interference in everyday life by revealing the social reflections of spatial injustice. Transformed spaces designed and produced by focusing on cost, rent and quantity do not satisfy to daily needs. Rather than the qualitative and quantitative adequacy of the reinforcement, it is important how it satisfy to the needs of the society it serves and to the desire for daily life.

People who cannot live in the transformed areas and do not feel that they belong to there have to move from that area over time. These actions aimed at segregation and indirect displacement deepen the differences within the city. In fact, for citizens, leaving the area they live in means much more than leaving to move. What is left behind is not just land; cultural environment, sense of belonging and comfort zone. At this point, the main concern of planning should be people. It should be a guide in producing new cities for everyone together with the citizens. This is how it is possible to unlock planning. 


\section{References}

Aksoy, A. (2014) 'İstanbul'un neoliberalizmle imtihanı' in C. Özbay and A. Bartu Candan (eds.), Yeni İstanbul Çalışmaları Sınırlar, Mücadeleler, Açılımlar. İstanbul: Metis Yayıncılık, pp. 27-47.

Ataöv, A. and Osmay, S. (2007) 'Türkiye'de kentsel dönüşüme yöntemsel bir yaklaşım', METU Journal of The Faculty of Architecture, 24(2), pp. 57-82.

Atkinson, R. (2003) 'Domestication by cappuccino or a revenge on urban space? Control and empowerment in the management of public spaces', Urban studies, 40(9), pp. 1829-1843.

Atkinson, R. and Bridge, G. (2005) Gentrification in an global context: The new urban colonialism. London: Routledge.

Bourdieu, P. (1995) Pratik nedenler. Translated by H. Tufan. İstanbul: Kesit.

Brenner, N. and Theodore, N. (2002) 'Cities and the geographies of "actually existing neoliberalism"'. Antipode. 34(3), pp. 349-379.

Brenner, N. (1999) 'Globalisation as reterritoralisation: The rescling of urban governance in European Union. Urban Studies, 36(3), pp. 431-451.

Castells, M. (1994) 'European cities, the information society ant the global economy'. New Left Review, 204, 18-32.

Connerton, P. (2011) Modernite nasıl unutturur?. Translated by K. Kelebekoğlu. İstanbul: Sel Yayıncılık.

Crawford, M. (2005) 'Everyday urbanism' in R. Mehrotra (eds.), Michigan Debates on Urbanism. Ann Arbor: The University of Michigan, pp. 16-34.

Çavuşoğlu, E. (2014) Türkiye kentleşmesinin toplumsal arkeolojisi. İstanbul: Ayrıntı.

Debord, G. (1984) Society of the spectacle. New York: Black \& Red.

De Certeau, M. (2011) Practice of Everyday Life, 3rd edition, California: University of California.

Durkheim, E. (1976) The elementary forms of the religious life. London: Routledge.

Fischer, C. S. (1975) 'Toward a subcultural theory of urbanism'. American Journal of Sociology, 80(6), pp. 13191341.

Giddens, A. (1999) The third way. London: Polity Press.

Harvey, D. (2008) 'The right to the city'. The City Reader, 6(1), pp. 23-40.

Jacobs, J. (1961) The death and life of great american cities. New York: Vintage Books.

Jameson, F. (2008) Modernizmin ideolojisi. Translated by K. Atakay, T. Birkan. İstanbul: Metis Yayınları.

Kiper, P. (2004) 'Küreselleşme sürecinde kentlerimize giren yeni tüketim mekânları ve yitirilen kent kimlikleri'. Planlama Dergisi, 4, pp. 14-18.

Lees, L. (2008) 'Gentrification and social mixing: towards an inclusive urban renaissance?'. Urban Studies, 45(12), pp. 2449-2470.

Lefebvre, H. (1971). Everyday life in the modern world. London: Harper \& Row

Lefebvre, H. (2006). Critique of everyday life, vol. 2. Translated by John MoorePreface and Michel Trebitsch, Londra: Verso Books.

Lefebvre, H. (2014). Mekânın Üretimi. (ı. Ergüden, Çev.). İstanbul: Sel Yayıncılık.

Lovering, J., and Türkmen, H. (2011) 'Bulldozer neoliberalism in Istanbul: The state-led construction of property markets, and the displacement of the urban poor'. International Planning Studies, 16(1), pp. 73-96.

Molotch, H. (1976) 'The city as a growth machine: Toward a political economy of place'. American journal of sociology, 82(2), pp. 309-332. 
Park, R.E. at all. (1925) The city. Berkeley: University of California Press.

Simmel, G. (1996). 'Metropol ve zihinsel hayat'. Translated by B. Ö. Düzgören. Cogito, 8, i̇stanbul: iletişim, pp. 81-89.

Smith, N. (1996) The new urban frontier: gentrification and the revanchist city. London: Routledge.

Smith, N., and Williams, P. (eds.) (2013) Gentrification of the city. New York: Routledge.

Şenyapılı, T. (1998) 'Cumhuriyet'in 75. yilı Gecekondunun 50. Yılı'. in Y. Sey (ed.), 75 yılda Değişen Kent ve Mimarlık. İstanbul: Tarih Vakfı, pp. 301-316.

Tekeli, İ. (2000) ‘Gündelik hayat üzerine düşünceler'. In F. Atacan, F. Ercan, H. Kurtuluş and M. Türkay (eds.), Mübeccel Kıray Için Yazılar. İstanbul: Metis Yayıncılık, pp. 339-355.

Tekeli, i. (2001) Modernite aşılırken kent planlaması. İstanbul: İmge Kitabevi.

Tekeli, i. (2011) Kent, kentli hakları, kentleşme ve kentsel dönüşüm yazıları. İstanbul: Tarih Vakfı Yurt Yayınları.

Tönnies, F. (1988) Community and Society. Translated by Charles P.Loomis. Oxford: Transaction Books.

Türkün, A. (ed.) (2014) Mülk, mahal, insan: Istanbul'da kentsel dönüşüm. İstanbul: Istanbul Bilgi Üniversitesi Yayınları.

Ünsal, Ö. (2014). Neoliberal kent politikaları ve direnişin siyaseti: İstanbul'da yeni kentsel muhalefet. in C. Özbay, A. Bartu Candan. Yeni İstanbul Çalışmaları Sınırlar, Mücadeleler, Açılımlar. İstanbul: Metis Yayıncılık, pp. 109-127.

Wirth, L. (1964) Urbanism as a way of life. Chicago: Chicago University Press, pp 60-83.

Yalçıntan, M.C. and Çavuşoğlu, E. (2010) 'Küresel İstanbul tahayyülünün eleştirisi'. Mimarlık, 356, pp. 34-37.

Zukin, S. (1995). The cultures of cities. Oxford: Blackwell. 